\title{
The European Integration in the Midst of the COVID-19: Challenges and Opportunities
}

\author{
Bitwoded Admasu Dagnaw \\ College of Social Sciences and the Humanities, University of Gondar, Gondar, Ethiopia
}

\section{Email address:}

bitwodedadmasu@gmail.com, bitwodedad@yahoo.com

\section{To cite this article:}

Bitwoded Admasu Dagnaw. The European Integration in the Midst of the COVID-19: Challenges and Opportunities. International Journal of European Studies. Vol. 4, No. 2, 2020, pp. 37-40. doi: 10.11648/j.ijes.20200402.11

Received: June 10, 2020; Accepted: June 30, 2020; Published: August 10, 2020

\begin{abstract}
The European Union is an intelligentsia that dreamed of a new Europe. The EU used technical and administrative skills to build the foundation of a new Europe. The purpose of this article is to examine the challenges and opportunities of the European Integration after the COVID 19 development. The researcher employed document analysis, Books, reports, brushers, leaflets, journals and articles as a source of secondary data. The data was analyzed by using thematic analysis for the qualitative data. The findings of the study showed that New European Union strategy and principles should be timely and relevant that should be stated in various European Union documents on any possible pandemic eruption. The nuisance prevention management and resolution should be translated in to a set of operational and implementation guide lines. The European Union should use its position as a major international player and historic partner to persuade international organizations to respond to any possible pandemic accordingly. Based on the findings of the study, the researchers recommended that the European Union development frame work should no longer focus merely on short term macro-economic issues instead the EU should also embrace social health and structural issues in a long term vision for the European Union Community. The EU and health professionals seek to answer pandemic challenges and promote the creation of a consistent, fair and professionally controlled health policy for the EU. The European Union should also use its position as a major international player to persuade international organizations, and its counterparts of the African Union to respond to pandemic defy accurately as well.
\end{abstract}

Keywords: European Union, COVID-19, Strategies, Integration, Pandemic

\section{Introduction}

Europe has been one of the world's most indispensable economic, political and cultural centers. The European Union is the most remarkable political and economic integration of an intelligentsia that dreamed of a new spectacular Europe. The integration course of action began in part as an effort by the prominent European political leaders to overcome the national rivalries that had led to two world wars in the first half of the twentieth century. However, other social theorists argue that the EU emerged during the Cold War period to counter balance American dominance in the global arena. That's why member states leave behind and shed some sovereign political and economic issues for genuine integration. In fact, after a successive political instability and dreadful world wars the European integration project was most likely to emerge. The contemporary political developments have been leaning towards to integration. "In a world dominated by the international systems of the two nuclear super powers, many countries willingly accepted constraints on their national sovereignty" [2].

This grand and inspirational union started with the initiative of the two remarkable German and French foreign ministers [1] The fundamental beliefs of the Schuman Plan [15], which created rules for a common Steel, Iron and Coal market, was to withdraw French and German basic industries from national authority in order to make another war impractical with the possibilities of other European states would join them. Thus, in this regard, the underlying philosophy of the plan was to pull out French and German basic industries which served to resolve competition between

France and Germany place their coal and steel industries under joint management, [1] Robert Schuman (1886-1963) best known for proposing that he was ideally suited to the 
task of bringing about a reconciliation between these two former enemies, whereas Konrad Adenauer (1876-1967) as the first chancellor (1949-1963) of the Federal Republic of Germany. Adenauer was responsible for making West Germany a founding member of the EC. After WWII he helped to draft the West German constitution and to found a new political party the Christian Democratic Union [Oudenaren J. Van, 2005:p. 34].

[2] The Ever Changing Union: An Introduction to the History, Institutions and Decision Making Process of the European Union. Centre for European Policy Studies. [Egenhofer C., Kurpas S., and Van Schaik L., 2009:p. 4-7].

European nations over natural resources and to focus on economic co-operation rather. Likewise Italy, Belgium, Luxembourg and the Netherlands decided to join France and Germany. "In political terms, the ECSC can be considered a success, not least because it was a first important step in the European integration process" [2].

\section{Method}

The method for this study employed document analysis, books, reports, brushers, leaflets, journals and articles as a source of secondary data. The data was systematically analyzed by using thematic analysis for the qualitative data. The treaty constituting the European Coal and Steel Community supposed to be based on a common market, common objectives and common institutions [9]. An early move towards political union was the attempt to create a European Defence Community. Following the successful launch of the ECSC, the defence communities anticipate the integration of the armies of the abovementioned six ECSC member states into a European army. However, the project was far from a realization since the French Parliament of the National Assembly was not comfortable to approve the treaty for fear of relocating sovereignty over national defence policy.

[3] "The mission of the European Coal and Steel community is to contribute to economic expansion, the development of employment and the improvement of the standard of living in the participating countries through the institution, in harmony with the general economy of the member states, of a common market as defined in Article 4" [3].

\subsection{The Objective of the Lisbon's Treaty}

Lisbon's treaty [5] projected to make the European Union more democratic, efficient and transparent. Consequently, Central and Eastern European countries membership and enclosure to the European Union has been an extraordinary attainment of the principal objectives behind systemic renovation sought by previous member states. It proved to be the significant for the consolidation of European Union development of economy and democracy.

[4] Treaty of Lisbon has given more powers to the democratically elected European Parliament and introduced an element of direct democracy with the European Citizens' Initiative. "The Ever-Changing Union: An Introduction to the History, Institutions and Decision-Making Processes of the
European Union" [4].

It has been said that the EU used to focus on the issue of the protection of civil, political, economic, social cultural rights. Additionally the protection includes minorities, ethnic groups, and indigenous peoples as well as support for the institutions and bodies that work to protect and defend human rights [14]. The European Union development frame work should no longer focus merely on short term macroeconomic issues as it did previously. It should therefore further embrace social health and structural issues in a long term vision for the European society. "The EU politicians see international problems in more nuances and certainly prefer solutions using political and economic instruments" [5]. If the European Union bravery to follow such a course, not only will be able to save the European community from any pandemic danger but it can also transform in to a reliable Union. The issue of health and human lives must be given prime consideration as the primary national security interest. Parallel to the issue of Human rights, the European Union and other international organizations should give enough attention for the issue of pandemic. According to Alston, "the EU must encourage the formation of a consistent, reasonable and competently controlled human rights policy issues for the Union" [14]. In addition to the above constructive proposition of Alston, it is timely and urgent that the EU must bestow enough attention for the issue of any possible pandemic in any one of the member states any instance.

[5] As the EU continues to grow in importance, both as a force in international relations and as an ever more important influence, its approach to human rights will become increasingly significant" [14]. Moreover, Lammy attests that in May 1995, in response to a Commission Communication, the council approved a suspension mechanism to be included in agreements with third countries to enable the community to react immediately in the event of serious and persistent human rights \& funds are allocated to the promotion and defence of human rights and fundamental freedoms [13].

\subsubsection{The European Partnership for Health Strategies for Member States}

The argument here is there must be what the researcher called the NEPHS (New European Partnership for Health Strategies for member states) that shall be aimed to restrain any possible pandemic outbreak in the Union. Thus, the NEPHS must be a central and systematized health principle for the partnership strategies directed by health professionals for the European Union. "The EC regime has become institutionalized over the decades, and although the national interests of the EC's member states are far from harmonious, the EC has provided the institutional framework which as reduced uncertainty, facilitated communication and information, and has overcome the obstacles to collective action" [1].

In fact, the current movement of the European network for the promotion of health enhancing activity and the European Forum of National Nursing and Midwifery Associations is quite encouraging. However, still the European Health systems and policies should be improved and changed. In 
recent years, World Health Organization's involvement in partnerships and similar collaborative arrangements for health has grown considerably. "The institutional arrangements for the growing number of partnerships have become increasingly complex" [11].

\subsubsection{The European Union Health Policy Mechanisms}

It is pressing urgent and imperative the Europe Union can mobilize its intellectual resources and health professionals as well. It is remarkable that previously the European Union applies various economic and political partnership agreements consistently to promote human rights, democracy and good governance in and outside the union. However, the EU particularly drives towards further consolidation of its international dimension for prestige. Otherwise this is well attested by milczarek, "by the necessity to protect its various interests of political, economic, military or social and cultural nature and to satisfy its ambitions and the need of prestige" [5]. If the EU in co-operation with international health organizations mobilized the European health professionals, and intellectual resources to curtail any pandemic like the COVID-19 crisis, it will steadfastly resolve the present and future pandemic difficulties the EU is facing which in turn improve the global health strength of the world.

\subsection{The European Union Reaction to COVID-19}

It is stirring and heartening that all through these times of crisis, the EU and its member states are working together and helping each other [6]. The EU and its member states are working together to reinforce national healthcare systems and contain the spread of the virus. The EU and its member states are taking action to alleviate the economic and social impact of COVID-19.

[6] The EU has already mobilized resources to support the emergency response to the virus: ensuring supply of protective equipment, boosting research and supporting our global partners in need [19].

The EU's response to COVID-19 centered on four priorities, i.e. limiting the spread of the virus, ensuring the provision of medical equipment, promoting research for treatments and vaccines, supporting jobs, businesses and the economy [7]. These priorities were agreed on by EU leaders who regularly meet by video conference to discuss and assess the EU's response to the pandemic outbreak. "On 23 April 2020, EU leaders endorsed a $€ 540$ billion package of three safety nets for workers, businesses and member states and the EU has committed to a global response package of $€ 20$ billion to support partner countries' efforts in fighting the pandemic as well" [7].

[7] The European Commission, May 2020.

\subsection{The Solidarity Measures of the European Union}

In addition to an agreement of a work towards establishing a recovery fund co-operation to challenge the pandemic is critical. It is obvious that this pandemic is a global challenge and requires a shared and united global response [8] as the President of the European Council express it.

[8] "Only a shared spirit of global solidarity and responsibility will defeat the COVID-19 crisis". [17].

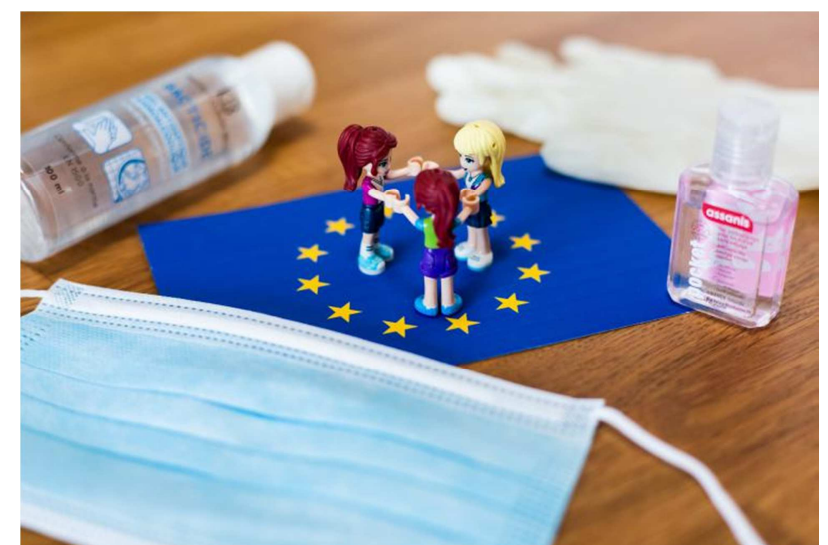

Figure 1. The European Union flag surrounded by a surgical mask, a medical glove and a hydro-alcoholic solution (Source: EC Audiovisual Service).

The EU engaged critically with the challenges that the pandemic brought forward. It has announced solidarity measures for the countries most affected by the crisis with the transfer of medical equipment and teams being at the spearhead of this effort. It has also announced a financial aid package to support partner countries with more than 20 billion Euros [9] Had the European Union maintained splendid health policy mechanisms to deal with pandemic related challenges, it would have been easy to deal with the problem and save the worst-hit countries in the Union since the first confirmed cases in Europe in the month January 2020.

[9] Being a values-based organisation, it has also taken special care to protect human rights, democracy and the rule of law during this period. In that respect its cooperation with the Council of Europe is of particular importance [18].

\section{Result}

It is breathtaking that the EU officials were quick to underline the challenges that this situation posed with regard to the pandemic. The officials have raised issues relating to the exacerbation of domestic violence the further social distancing of people. It is, indeed, crucial that the Secretary General of the Council of Europe has issue for governments across Europe on respecting human rights, democracy and the rule of law during the COVID19 crisis. It is quite motivating that the EU is taking active measures to care for the employers and employees and to maintain their social and economic rights [10]. "Globally, as of $12: 35 \mathrm{pm}$ CEST, 9 June 2020, there have been $7,039,918$ confirmed cases of COVID-19, including 404,396 deaths" (16).

Table 1. The latest development of the COVID-19 Case comparison. (Source: World Health Organization; Data last updated: 2020/6/9, 12:35pm).

\begin{tabular}{lll}
\hline No. & WHO Regions & Confirmed Cases \\
\hline 1 & USA & $3,366,251$ \\
2 & Europe & $2,303,361$ \\
3 & Eastern Mediterranean & 658,614 \\
4 & South-East Asia & 378,118 \\
5 & Western Pacific & 192,335 \\
\hline
\end{tabular}




\begin{tabular}{lll}
\hline No. & WHO Regions & Confirmed Cases \\
\hline 6 & Africa & 140,498 \\
\hline
\end{tabular}

\section{Discussion}

The EU has called upon member states to make certain that susceptible people received the essential support during the pandemic as well.

[10] The effort includes the new financial instrument SURE proposed by the Commission with the aim of protecting jobs and workers affected by the corona virus pandemic [19].

It seems that European Union and the United States of America must stand united to restrain the pandemic more than ever. The United States Shared values and interlocking culture with Europe through the Anglo-Saxon tradition. The real [11] bond between the United States and Europe is the values shared such as democracy, individual freedom, human rights and the rule of law and these values crossed the Atlantic with those who sailed from Europe to help create the United States of America.

[11] Alojzy Z., Borkowski J. and Dariusz M. Year Book of Polish: European Studies; Warsaw University Centre for Europe Volume 7/2003 [p. 97].

\section{Conclusion}

It is appropriate to presume that mankind will learn from its mistakes and that nations and governments will grow wiser and more pacific as centuries go by, along similar lines as technology and the sciences have developed over the ages. Currently, the EU is in need of an organized pandemic defence shield strategies. The EU should get on with a special concern to contain this novel pandemic crisis and embarked in to new development co-operation strategies by instigating its member states to fight against COVID-19 and other related pandemic problems. On one hand this string cooperative effort would lead to the new solution for the European security and pandemic zilch development. On the other hand the new cooperative strategies, as an opportunity, will improve European Union's ability to offer the necessary answers to the challenges of other similar global pandemic and related global challenges. The European Union development frame work should not merely focus merely on short term macro-economic issues. The EU should also embrace health, social, and structural issues in a long term vision for the European society. In addition to the issue of human rights, the EU development objective should make certain that a range of policies, including trade and development and the aid given to the least developed countries contribute effectively to the elimination of pandemics and poverty as well. An innovative European Union Health strategy and principles should be assured in various European Union member states binding documents. For any possible pandemic eruptions, prevention management and resolution mechanisms should be translated in to a set of operational and implementation guide lines. By mobilizing health professionals and available resources on the ground, the European Union should provide proper response to the current pandemic challenges. Furthermore, the EU should use its position as a major international player to persuade international organizations, and developing countries to respond to pandemic swiftly.

\section{References}

[1] Van Ham Peter, The EC. Eastern Europe and European Unity: Discord, Collaboration and Integration since 1947. St. Martin's Press. USA. 1993.

[2] Davies Norman. Heart of Europe: The Past in Poland's Present. Oxford University Press. 2001.

[3] Europe: A History. Oxford University Press. 1996.

[4] MacIver, R. M. The Modern State. Oxford University Press. 2006.

[5] Alojzy Z. Nowak, Jan Borkowski and Dariusz Milczarek; Year Book of Polish: European Studies; Warsaw University Centre for Europe Volume 7/2003.

[6] Alojzy Z. Nowak, Jan Borkowski and Dariusz Milczarek; Year Book of Polish: European Studies; Warsaw University Centre for Europe Volume 8/2004.

[7] European Centre for Disease Prevention and Control Risk assessment on COVID-19, 23 April 2020.

[8] Cornwell R. D. World History in the Twentieth Century. Produced by Longmans Singapore Publishers Pte. Ltd. Singapore. 1980.

[9] Friedmann, LL. D. W. An Introduction to World Politics. The Macmillan Company of Canada Limited. St Martin's Press INC. NewYork. USA. 1953.

[10] Richard Young. The European Union and the Promotion of Democracy. Oxford University Press 2001.

[11] World Health Organization Report (WHO).2010.

[12] Ian M. and Richard G., Whiteman. The Foreign Policies of European Union Member States. Manchester University Press. 2000.

[13] Lammy, Betten and Nicholas G. European Union Law and Human Rights, Addison Wesley Longman Publisher. 1998.

[14] Philip Alston. The European Union and Human Rights. Oxford University Press. 1999.

[15] Oudenaren V. John. Uniting Europe: An Introduction to the European Union. Rowman and Little Field Publishers, INC. Lanham. Boulder. NewYork. Toronto. Oxford. 2005.

[16] Van Seters Jeske and Klavert Henrike. EU Development Cooperation after the Lisbon Treaty People, Institutions and Global Trends. 2011

[17] Charles Michel, President of the European Council, April 2020.

[18] European Council May 2020.

[19] European Commission, 2020. 